\title{
Елеваторні потужності по областям України: Рейтинг за 2019 р.
}

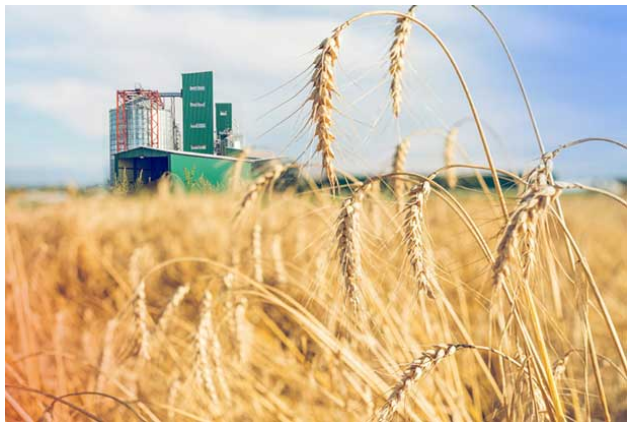

У 2019 елеваторні потужності України, за даними Карти елеваторів сайту Elevatorist.com склали близько 51 млн т одноразового зберігання. У ці потужності входять фермерські, портові, примлимнові елеватори, а також зерносховища, для комбікормових заводів і ОЕЗів. 3 них на даний момент підлогові склади займають $35,7 \%$, СОГі - 20,6\%, металеві силоси $43,7 \%$ від загального обсягу зберігання.

У порівнянні з минулим роком, елеваторна галузь збільшила потужності зі зберігання зернових і олійних культур на 3 млн т.

Будівництво йшло майже у всіх регіонах України. Найбільше - на 412 тис. т. більше, в порівнянні з 2018 року, додала елеваторних потужностей Вінницька область, за рахунок чого вона піднялася на одну позицію вгору, на 4 місце.

Серед лідерів як і раніше три області - Полтавська, Одеська і Миколаївська. Однак в 2019 році, як і в 2018-му, знову перше і друге місця помінялися: як і два роки тому лідирує Полтавська область, тут елеваторні потужності збільшилися на 350 тис. т. Сумська область додала 325 тис. т за рахунок будівництва нових великих елеваторів, що допомогло їй переміститься з 10 на 9 місце. Третє місце стабільно і міцно утримує Миколаївська область.

\begin{tabular}{|c|c|c|}
\hline № & Область & Характеристика елеваторної потужності \\
\hline 1 & $\begin{array}{l}\text { Полтавська } \\
\text { область } \\
28748 \text { км² }^{2}\end{array}$ & $\begin{array}{l}\text { Елеваторні потужності: } 4918000 \text { т, дефіцит - 0,9 млн.т. Кількість діючих елеваторів - 99, } \\
\text { сертифікованих - 72. Склади підлогового зберігання займають } 29,8 \% \text {, СОГі - 14,9\%, металеві } \\
\text { силоси - 54,8\% від загального обсягу зберігання зернових культур. } \\
\text { Валовий збір у } 2019 \text { році } 6122,41 \text { тис. т зернових і олійних культур. }\end{array}$ \\
\hline 2 & $\begin{array}{l}\text { Одеська } \\
\text { область } \\
33310 \text { км² }^{2}\end{array}$ & $\begin{array}{l}\text { Елеваторні потужності: } 4752340 \text { т, дефіцит - 0,7 млн.т. Кількість діючих елеваторів - 83, } \\
\text { сертифікованих - 81. Склади підлогового зберігання займають } 34,5 \% \text {, СОГі - 13,0\%, металеві } \\
\text { силоси - 51,5\% від загального обсягу зберігання зернових культур. } \\
\text { Валовий збір у } 2019 \text { році } 3725,33 \text { тис. т зернових і олійних культур. }\end{array}$ \\
\hline
\end{tabular}

Елеваторні потужності: 3973600 т . Кількість діючих елеваторів - 64 .

$32 \log _{0}$ Миколаївська Склади підлогового зберігання займають 50,2\%, СОГі - 14,1\%, металеві силоси - 32,6\% від

область $\quad$ загального обсягу зберігання зернових культур.

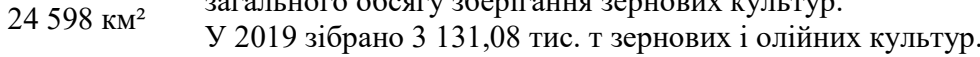

\begin{tabular}{|c|c|c|c|}
\hline 4 & & $\begin{array}{l}\text { Вінницька } \\
\text { область } \\
26513 \text { км² }^{2}\end{array}$ & $\begin{array}{l}\text { Елеваторні потужності: } 3743970 \text { т. Кількість діючих елеваторів - } 81 . \\
\text { Склади підлогового зберігання займають } 32,1 \% \text {, СОГі - 17,4\%, металеві силоси - 50,6\% від } \\
\text { загального обсягу зберігання зернових культур. } \\
\text { У } 2019 \text { зібрано 5994,66 тис. т зернових і олійних культур. }\end{array}$ \\
\hline 5 & & $\begin{array}{l}\text { Кіровоградсь- } \\
\text { ка область } \\
24588 \text { км² }^{2}\end{array}$ & $\begin{array}{l}\text { Елеваторні потужності: } 3534240 \text { т . Кількість діючих елеваторів - } 93 \text {. } \\
\text { Склади підлогового зберігання займають 37,8\%, СОГі - 21,2\%, металеві силоси - 40,4\% від } \\
\text { загального обсягу зберігання зернових культур. } \\
\text { У } 2019 \text { зібрано } 4 \text { 344,92 тис. т зернових і олійних культур. }\end{array}$ \\
\hline 6 & & $\begin{array}{l}\text { Дніпропет- } \\
\text { ровська об- } \\
\text { ласть } \\
23191 \text { км}^{2} \\
\end{array}$ & $\begin{array}{l}\text { Елеваторні потужності: } 2955344 \text { т. Кількість діючих елеваторів - } 83 . \\
\text { Склади підлогового зберігання займають 39,2\%, СОГі - 39,6\%, металеві силоси - 21,2\% від } \\
\text { загального обсягу зберігання зернових культур. } \\
\text { У } 2019 \text { зібрано } 4 \text { 282,21 тис. т зернових і олійних культур. }\end{array}$ \\
\hline 7 & & $\begin{array}{l}\text { Харківська } \\
\text { область } \\
31415 \text { км² }^{2}\end{array}$ & $\begin{array}{l}\text { Елеваторні потужності : } 2815359 \text { т. Кількість діючих елеваторів - } 80 . \\
\text { Склади підлогового зберігання займають 40,3\%, СОГі - 7,3\%, металеві силоси - 22,4\% від } \\
\text { загального обсягу зберігання зернових культур. } \\
\text { У } 2019 \text { зібрано } 4 \text { 414,79 тис. т зернових і олійних культур. }\end{array}$ \\
\hline 8 & & $\begin{array}{l}\text { Хмельницька } \\
\text { область } \\
20645 \text { км}^{2}\end{array}$ & $\begin{array}{l}\text { Елеваторні потужності: } 2690672 \text { т. Кількість діючих елеваторів - } 71 . \\
\text { Склади підлогового зберігання займають } 34,4 \% \text {, СОГі - 12,1\%, металеві силоси - 53,4\% від } \\
\text { загального обсягу зберігання зернових культур. } \\
\text { У } 2019 \text { зібрано } 3 \text { 793,95 тис. т зернових і олійних культур. }\end{array}$ \\
\hline 9 & & $\begin{array}{l}\text { Сумська } \\
\text { область } \\
23834 \text { км² }^{2}\end{array}$ & $\begin{array}{l}\text { Елеваторні потужності: } 2533890 \text { т. Кількість діючих елеваторів - } 52 . \\
\text { Склади підлогового зберігання займають 26,0\%, СОГі - 18,1\%, металеві силоси - 55,9\% від } \\
\text { загального обсягу зберігання зернових культур. } \\
\text { У } 2019 \text { зібрано } 4 \text { 439,52 тис. т зернових і олійних культур. }\end{array}$ \\
\hline 10 & & $\begin{array}{l}\text { Черкаська } \\
\text { область } \\
20900 \text { км² }^{2}\end{array}$ & $\begin{array}{l}\text { Елеваторні потужності: } 2416160 \text { т . Кількість діючих елеваторів - } 60 . \\
\text { Склади підлогового зберігання займають 42,6\%, СОГі - 11,4\%, металеві силоси - 46,0\% від } \\
\text { загального обсягу зберігання зернових культур. } \\
\text { У } 2019 \text { зібрано } 4 \text { 553,17 тис. т зернових і олійних культур. }\end{array}$ \\
\hline 11 & & $\begin{array}{l}\text { Київська } \\
\text { область } \\
28131 \text { км }^{2}\end{array}$ & $\begin{array}{l}\text { Елеваторні потужності: } 2330050 \text { т. Кількість діючих елеваторів - } 54 . \\
\text { Склади підлогового зберігання займають } 24,1 \% \text {, СОГі - 22,9\%, металеві силоси - 52,9\% від } \\
\text { загального обсягу зберігання зернових культур. } \\
\text { У } 2019 \text { зібрано } 4 \text { 196,83 тис. т зернових і олійних культур. }\end{array}$ \\
\hline
\end{tabular}


Чернігівська область 31865 км$^{2}$

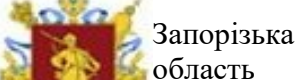

Елеваторні потужності: 2201860 т. Кількість діючих елеваторів - 62 .

Склади підлогового зберігання займають $35,4 \%$, СОГі - 9,1\%, металеві силоси - 55,0\% від загального обсягу зберігання зернових культур.

У 2019 зібрано 4 992,32 тис. т зернових і олійних культур.

Елеваторні потужності: 2169150 т. Кількість діючих елеваторів - 53.

Склади підлогового зберігання займають 47,6\%, СОГі - 34,5\%, металеві силоси - 17,5\% від загального обсягу зберігання зернових культур.

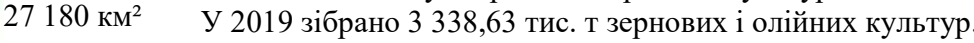

\section{Елеваторні потужності: 1867865 т. Кількість діючих елеваторів - 56.} 14 Ad oбласть $28461 \mathrm{\kappa м}^{2}$ Склади підлогового зберігання займають 42,5\%, СОГі - 31,5\%, металеві силоси - 24,1\% від загального обсягу зберігання зернових культур. У 2019 зібрано 2 738,14 тис. т зернових і олійних культур.

\section{Елеваторні потужності: 1656560 т. Кількість діючих елеваторів - 50.}

Склади підлогового зберігання займають $33,1 \%$, СОГі - 4,8\%, металеві силоси - 62,1\% від загального обсягу зберігання зернових культур.

У 2019 зібрано 2 687,75 тис. т зернових і олійних культур.

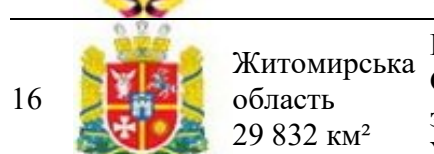

$29832 \mathrm{\kappa M}^{2}$

Елеваторні потужності: 1210370 т. Кількість діючих елеваторів - 45.

Склади підлогового зберігання займають $26,8 \%$, СОГі - $14,3 \%$, металеві силоси - 58,9\% від загального обсягу зберігання зернових культур.

У 2019 зібрано 2 728,98 тис. т зернових і олійних культур.

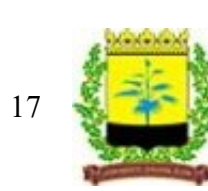

Донецька область $26517 \mathrm{KM}^{2}$

Елеваторні потужності: 1030330 т *. Кількість діючих елеваторів - 29.

Склади підлогового зберігання займають $20,1 \%$, СОГі - 50,1\%, металеві силоси - 29,8\% від загального обсягу зберігання зернових культур.

У 2019 зібрано 1967,07 тис. т зернових і олійних культур (без урахування неконтрольованих територій).

* Без урахування неконтрольованих територій

Елеваторні потужності: 862600 т *. Кількість діючих елеваторів - 20.

Склади підлогового зберігання займають $42,8 \%$, СОГі - 45,2\%, металеві силоси - $12,0 \%$ від загального обсягу зберігання зернових культур.

Луганська область $26684 \mathrm{\kappa M}^{2}$ У 2019 зібрано 1 445,48 тис. т зернових і олійних культур (без урахування неконтрольованих територій).

* Без урахування неконтрольованих територій

\begin{tabular}{|c|c|c|}
\hline 19 & $\begin{array}{l}\text { Рівненська } \\
\text { область } \\
20047 \text { км}^{2}\end{array}$ & $\begin{array}{l}\text { Елеваторні потужності: } 825570 \text { т. Кількість діючих елеваторів - } 22 . \\
\text { Склади підлогового зберігання займають } 23,2 \% \text {, СОГі - 20,9\%, металеві силоси - 55,6\% від } \\
\text { загального обсягу зберігання зернових культур. } \\
\text { У } 2019 \text { зібрано } 1484,66 \text { тис. т зернових і олійних культур. }\end{array}$ \\
\hline 20 & $\begin{array}{l}\text { Львівська } \\
\text { область } \\
21833 \mathrm{\kappa м}^{2}\end{array}$ & $\begin{array}{l}\text { Елеваторні потужності: } 768654 \text { т. Кількість діючих елеваторів - } 31 . \\
\text { Склади підлогового зберігання займають } 31,7 \% \text {, СОГі - 19,4\%, металеві силоси - 47,9\% від } \\
\text { загального обсягу зберігання зернових культур. } \\
\text { У } 2019 \text { зібрано } 1629,81 \text { тис. т зернових і олійних культур. }\end{array}$ \\
\hline 21 & $\begin{array}{l}\text { Волинська } \\
\text { область } \\
20144 \text { км}^{2}\end{array}$ & $\begin{array}{l}\text { Елеваторні потужності: } 715000 \text { т. Кількість діючих елеваторів - } 26 . \\
\text { Склади підлогового зберігання займають } 37,2 \% \text {, СОГі - 17,2\%, металеві силоси - 42,2\% від } \\
\text { загального обсягу зберігання зернових культур. } \\
\text { У } 2019 \text { зібрано } 1291,6 \text { тис. т зернових і олійних культур. }\end{array}$ \\
\hline 22 & $\begin{array}{l}\text { Івано- } \\
\text { Франківська } \\
\text { область } \\
13900 \text { км² }^{2}\end{array}$ & $\begin{array}{l}\text { Елеваторні потужності: } 440510 \text { т. Кількість діючих елеваторів - } 9 . \\
\text { Склади підлогового зберігання займають 7,2\%, СОГі - 22,2\%, металеві силоси - 70,6\% від } \\
\text { загального обсягу зберігання зернових культур. } \\
\text { У } 2019 \text { зібрано 743,03 тис. т зернових і олійних культур. }\end{array}$ \\
\hline 23 & $\begin{array}{l}\text { Чернівецька } \\
\text { область } \\
8097 \mathrm{\kappa м}^{2}\end{array}$ & $\begin{array}{l}\text { Елеваторні потужності: } 230600 \text { т. Кількість діючих елеваторів - } 9 . \\
\text { Склади підлогового зберігання займають } 37,6 \% \text {, СОГі - 24,3\%, металеві силоси - 38,1\% від } \\
\text { загального обсягу зберігання зернових культур. } \\
\text { У } 2019 \text { зібрано 642,03 тис. т зернових і олійних культур. }\end{array}$ \\
\hline 24 & $\begin{array}{l}\text { Закарпатська } \\
\text { область } \\
12777 \text { км² }^{2}\end{array}$ & $\begin{array}{l}\text { Елеваторні потужності: } 94450 \text { т. Кількість діючих елеваторів - 3. Склади підлогового збе- } \\
\text { рігання займають } 21,0 \% \text {, СОГі - 5,5\%, металеві силоси - 73,5\% від загального обсягу збері- } \\
\text { гання зернових культур. } \\
\text { У } 2019 \text { зібрано } 389,45 \text { тис. т зернових і олійних культур. }\end{array}$ \\
\hline
\end{tabular}

Джерело: https://elevatorist.com 